\title{
Changes in Plasma Proteins During Pregnancy*
}

\author{
JEAN CURLEY JOSEPH, Ph.D., CATHERINE BAKER, Ph.D., \\ MILTON L. SPRANG, M.D. and EDWARD W. BERMES, Ph.D. $\uparrow$ \\ Departments of Pathology and Biochemistry and Biophysics, \\ Loyola University Medical Center, \\ Maywood, IL 60153 \\ and \\ St. Francis Hospital and Evanston Hospital, \\ Evanston, IL 60201
}

\begin{abstract}
Changes in maternal plasma proteins during pregnancy are now well documented. These changes may be quantitative, as seen in the electrophoretically separated fractions of serum and in the various binding globulins; or they may be represented by the appearance of a protein which is present only in the serum of pregnant women. These include the placental isoenzyme of alkaline phosphatase, oxytocinase, human chorionic gonadotropin and the "pregnancy-associated plasma proteins." Other constituents, such as $\alpha$-fetoprotein, salivary amylase, prolactin and the proteins of the "pregnancy zone," which are present in small quantities in nonpregnant women as well as in men, show a substantial increase in concentration in the maternal circulation during pregnancy. An important factor in the etiology of protein changes is the effect of hormones, especially estrogen, on the synthesis and degradation of these proteins.

While certain quantitative changes such as those seen in hormone binding proteins may interfere with diagnostic procedures, a number of pregnancy-associated changes in protein composition of the maternal circulation may be used to follow the course of pregnancy by monitoring placental function as well as fetal maturity and well being.
\end{abstract}

\section{Introduction}

As early as 1930 , unusual characteristics were noted in the serum of pregnant women, namely the ability of such serum

* Supported in part by a NIH Research Training Grant in Clinical Chemistry 5 T01 GM02122-04.

† Reprint requests should be sent to Edward W. Bermes, Ph.D., Departments of Biochemistry and Pathology, Loyola University Medical Center, Maywood, IL 60153. to deactivate oxytocin. ${ }^{17}$ Changes in maternal plasma or serum proteins during gestation are now well documented. These changes may be either in quantity of existing proteins or in production of proteins unique to pregnancy. For example, changes are noted in the levels of the electrophoretic fractions, specifically, albumin and the globulins as well as fibrinogen. Concentrations of the various 
binding globulins tend to increase during pregnancy. Other constituents, such as $\alpha$-fetoprotein, salivary amylase and the proteins of the "pregnancy zone" are present in small quantities in nonpregnant women and in men. However, the concentration in maternal circulation increases substantially during pregnancy.

In addition, there are a number of proteins which are present only in the serum of pregnant women. These include the placental isoenzyme of alkaline phosphatase, oxytocinase, human chorionic gonadotropin and the "pregnancyassociated plasma proteins." The concentrations of these proteins tend to rise during gestation and disappear within days to weeks postpartum.

A number of the pregnancy-associated changes in protein composition of the maternal circulation have been used to follow the course of pregnancy, to monitor placental function and to assess fetal maturity and well-being.

\section{Changes in Plasma Protein Concentration}

A fall in the concentration of total protein occurs during pregnancy. The extent of this fall and the pattern of change were the major differences encountered in numerous investigations. In some cases a continuous reduction in total protein during pregnancy was seen, ${ }^{12,62}$ while in others a stable period after the second trimester ${ }^{49}$ or a rise in concentration prior to delivery, ${ }^{5,39}$ or a drop in concentration after delivery ${ }^{62}$ were encountered with values returning to normal in 6 to 12 weeks postpartum. Discrepancies observed by the various investigators were thought to be the result of the random effects of individual variations.

The fall in protein concentration seen during pregnancy most likely is a result of the dilution of the plasma, since total protein concentration is inversely related to plasma water concentration. ${ }^{58}$ The abrupt increase in protein concentration seen be- fore labor $^{39}$ corresponds to a decrease in plasma water, while the rapid fall in concentration seen within 12 to 24 hours after delivery ${ }^{62}$ is the result of the mobilization of the excess extracellular fluid of pregnancy.

The concentration of albumin also decreases in pregnancy. ${ }^{12,28}$ The total amount of albumin is apparently unchanged; decreases in concentration are thought to be the result of an increase in plasma volume. ${ }^{58,60}$ In metabolic studies utilizing ${ }^{131}$ I-labeled albumin, Hönger and coworkers ${ }^{27}$ have shown that the total circulating albumin, the catabolic rate and the rate of synthesis are unchanged in normal pregnant women. It is possible that the increased albumin synthesis normally stimulated by sustained hypoalbuminemia is inhibited in pregnancy by progesterone or estrogen, since administration of estrogen causes a decrease in albumin concentration in non-pregnant individuals. ${ }^{36,54}$

The extent of change in the globulin fractions varied from study to study. A slight but significant rise in $\alpha_{1}$-globulin from early pregnancy to delivery, followed by a return to normal values by four weeks postpartum was found in some studies. ${ }^{56}$ In others, no significant variation during pregnancy was found, but rather an increase within the first week postpartum and a return to normal levels six to seven weeks after delivery. ${ }^{5,62}$

The changes in $\alpha_{2}$-globulins are similar. A significant rise in $\alpha_{2}$-globulin occurs throughout pregnancy, especially during the third trimester. ${ }^{12,58} \mathrm{~A}$ rise in concentration in the first week postpartum has been observed ${ }^{5}$ with values returning to normal within several weeks.

$\beta$-Globulins also rise during pregnancy. The elevation is significant throughout pregnancy. ${ }^{58}$ One study, however, showed no change in $\beta$-globulin until shortly before delivery, at which time an abrupt rise until the first 
week postpartum was seen, with a return to normal by six weeks after delivery. When $\beta$-globulin concentration was expressed as percent total protein, the increase was seen in the first trimester. ${ }^{5}$

It is agreed that there is an increase in the total amount of $\alpha$ - and $\beta$-globulins. This increase is large in relation to the total amount of protein present. The differences in the amount of changes observed in the various studies are probably the result of individual variations in plasma dilution during pregnancy.

There is a fall in the concentration of $\gamma$-globulin during pregnancy with a return to normal in 6 to 12 weeks. ${ }^{5,12}$ This is apparently a result of a decrease in the concentration of IgG. ${ }^{28,70}$ However, when $\gamma$-globulin concentration is expressed as percent total prote in, little change is seen.

Since albumin concentration decreases and the $\alpha$ - and $\beta$-globulin concentrations increase, there is a sharp decline in the albumin/globulin ratio during pregnancy.

An increase in fibrinogen has also been seen during pregnancy especially during the third trimester. ${ }^{5,12}$ The increase in fibrinogen is thought to be in anticipation of the trauma of delivery. ${ }^{12}$ The activities of prothrombin and serum prothrombin accelerator increase during normal pregnancy. ${ }^{5}$ Since no significant change in clotting time has been found during pregnancy, ${ }^{31}$ changes in clotting factors must represent compensatory alterations to maintain normal clotting times. ${ }^{5} \mathrm{~A}$ decrease in platelets occurs during early labor; however, there is a definite stimulus to platelet production during advanced labor. ${ }^{31}$ During the first six weeks postpartum, the increased levels of platelets, prothrombin and fibrinogen may be a contributory factor in the increased incidence of thrombosis during that period. ${ }^{31}$

\section{Binding Proteins}

During pregnancy, the concentrations of binding proteins in serum generally in- crease. The concentration of ceruloplasmin, an $\alpha_{2}$-globulin which binds copper, increases early in gestation, sometimes as much as twofold, and along with this, the plasma copper concentration increases. ${ }^{23,51,70}$ The administration of estrogen to a non-pregnant individual also results in the elevation of ceruloplas$\min .^{55,70}$

Haptoglobin, an $\alpha_{2}$-globulin which binds hemoglobin, undergoes no variation during pregnancy ${ }^{10,56}$ or a small decrease. ${ }^{70}$ Administration of estrogen to non-pregnant individuals causes a fall in haptoglobin concentration. ${ }^{55,70}$ In view of the rise in concentration of other binding globulins, it is possible that these two factors may cancel out resulting in a normal level of haptoglobin.

Transferrin, the iron binding $\beta$-globulin, is increased during pregnancy. ${ }^{10,51,70}$ The reason for this increase is presently unclear. Administration of estrogen or progesterone to non-pregnant individuals, in some cases, caused plasma transferrin concentration to increase; therefore, the increase seen in pregnancy was assumed to be a result of increased blood levels of those hormones. ${ }^{36,70}$ In other studies, however, which showed no increase in transferrin after administration of estrogen, the increase during pregnancy was thought to represent an increased rate of production in response to an increased demand for iron. ${ }^{55}$

In 1956, it was determined that in pregnant women the percentage of thyroxine bound to thyroxine binding globulin (TBG) increased, while that bound to albumin decreased. This was one of the first indications that there was a change in the concentration of TBG. ${ }^{16}$ Since then, it has been established that there is is an increase in TBG during pregnancy ${ }^{1,73}$ with the concentration increasing from $3.6 \mathrm{mg}$ per $\mathrm{dl}$ normally to $9.0 \mathrm{mg}$ per $\mathrm{dl}$ in the second and third trimesters. The concentrations of thyroxine and triiodothyronine increase in the same manner, although proportionately less. ${ }^{53}$ This increase in 
TBG appears to be a result of the effects of estrogen, since administration of estrogens causes an elevation in TBG. ${ }^{36,55,73}$

An increase in transcortin, or cortisol binding globulin, is observed during pregnancy. ${ }^{15}$ While the percentage of cortisol distributed among transcortin, albumin and the unbound state remains constant, an absolute increase in unbound or free cortisol has been observed during pregnancy. ${ }^{15,67}$ This increase in free cortisol during pregnancy explains some of the alterations of laboratory findings such as leukocytosis and eosinopenia. Administration of estrogens results in an increase in the concentrations of both transcortin and free cortisol. ${ }^{55,67}$

As pregnancy progresses, $\alpha$-lipoprotein is at first lowered, but then returns to its normal level. $\beta$-Lipoprotein reacts in the same way until the 14 th week and then rises until the 36 th week after which time it falls greatly until delivery. The variations in $\beta$-lipoprote in occur in either the second or third trimester; maximum postpartum values are between the first and eighth days; and values approach normal by the 50 th day postpartum. ${ }^{62}$

Increases in the electrophoretic mobility of lipoproteins are also seen during pregnancy. ${ }^{5,62}$ The increase in nonesterified fatty acids and the fall in albumin during pregnancy favor the binding of fatty acid to lipoproteins. This binding increases the mobility of the lipoprotein fractions. ${ }^{33}$

The three major classes of lipoproteins,very low density lipoprotein (VLDL), low density lipoprotein (LDL) and high density lipoprotein (HDL), are all elevated in normal pregnancy. LDL and HDL become enriched by triglycerides as pregnancy progresses. Total and VLDL-apo $B$ increase, while LDLapo $B$ remains unchanged. ${ }^{25}$

In addition to transcortin, other steroid hormone binding proteins increase during pregnancy. One of these proteins is designated $\mathrm{SP}_{2}$, or steroid binding globulin, a protein of $\mathrm{MW} \mathrm{65,000.} \mathrm{It} \mathrm{is} \mathrm{present}$ in trace amounts in all normal sera, but during the first half of pregnancy, levels of $\mathrm{SP}_{2}$ rise rapidly and then gradually decrease. By five to ten weeks postpartum, values return to normal. ${ }^{6}$ The level of $\mathrm{SP}_{2}$ also rises in persons receiving oral contraceptives or estrogen therapy and, therefore, is apparently induced by steroid hormones.

\section{Miscellaneous}

Among other proteins undergoing changes during pregnancy is the pituitary hormone prolactin. Prolactin rises from $25 \mathrm{ng}$ per $\mathrm{ml}$ at ten weeks of pregnancy to $207 \mathrm{ng}$ per $\mathrm{ml}$ at term, after which there is a slow and progressive fall to normal levels by the seventh day postpartum. The rise during pregnancy is thought to be either a preparation of the breast for milk production or the result of an increase in the number and activity of lactotropes in the pituitary of pregnant women. ${ }^{68,82}$

The concentrations of polypeptide hormones change during pregnancy. Some studies have indicated that human pituitary thyrotropin (TSH) increases; but there is some controversy as to the extent of the increase and how soon after delivery the values return to normal ${ }^{30,38,50,61}$ Recently, however, changes in TSH during pregnancy have been determined using specific radioimmunoassay. ${ }^{8}$ This study has shown that there is an initial fall in TSH during the second and third months followed by a rise to normal values. The TSH levels during the second, third and fourth months have been found to be significantly lower than normal. The rise in TSH seen in previous studies was believed to be the result of the nonspecific methods of analysis used. ${ }^{21}$

There is a progressive rise in serum amylase from the sixth to the 25 th week, followed by a gradual fall to the end of pregnancy. Amylase values greater than normal have been found in 42 percent of patients during the second trimester and 22 percent of patients in the third trimester. Isoamylase analysis has revealed that 
the ratio of pancreatic to salivary isozymes is $1: 1$ in the first trimester, $1: 3$ in the second trimester and 1:1 during the third trimester. These changes in amylase activity may be a result of the hormonal alterations of pregnancy, preferential passage of amylase isozymes from mother to fetus, or an alteration in the clearance rate of amylase. ${ }^{24}$

$\alpha$-Fetoprotein (AFP) was first found in fetal calf and later in the human fetus. ${ }^{11}$ It is known to be present in very small quantities in normal adults and in larger amounts in the serum of pregnant women.

Since AFP is produced by the fetus, it has been suggested that elevated AFP levels in the maternal circulation might be useful in the antenatal diagnosis of fetal abnormalities. ${ }^{11}$ Transfer of AFP to the maternal circulation can occur through the placenta or amniotic fluid. Whereas the AFP concentration reaches a maximum at 32 weeks in maternal plasma, it peaks at 14 weeks in the fetus..$^{35}$ At term, fetal AFP levels are 300 to 600 times the maternal level. ${ }^{69}$ Elevated maternal levels of AFP during periods of fetal distress may result from increased AFP production by the fetus or from placental leakage of fetal elements. Distressed newborns apparently have higher than normal AFP levels. ${ }^{69}$

AFP levels in maternal plasma are known to rise excessively in early pregnancy if there are open neural tube defects in the fetus. No correlations could be found between peak AFP concentration and birth weight, ${ }^{24,37}$ parity or maternal age. ${ }^{37} \mathrm{~A}$ correlation has been found between sex of the fetus and the time at which the AFP maximum is reached. For female fetuses, the peak is reached in an average of 31 weeks, while for male fetuses the average is 33 weeks. ${ }^{11}$ Abnormally high AFP levels are nearly always associated with fetal death. ${ }^{11}$

$\alpha_{1}$-Antitrypsin $\left(\alpha_{1}-\mathrm{AT}\right)$ is a glycoprotein which is known to increase during acute inflammation and necrosis and also dur- ing pregnancy. ${ }^{20,48,70,75}$ Normally $\alpha_{1}$-AT accounts for 90 percent of the trypsin inhibitory capacity of plasma. During pregnancy, however, the $\alpha_{1}$-AT levels rise to such an extent that essentially all antitryptic activity comes from $\alpha_{1}-\mathrm{AT}^{20,48}$

$\alpha_{1}$-AT levels rise from the 12 th to the 27th week after which no further elevation is seen. By the sixth week postpartum, values return to normal. ${ }^{20}$ Changes in steroid hormone balance may be the cause of the increase..$^{20}$ Because there is little placental exchange of $\alpha_{1}$-AT, maternal and fetal levels do not correlate. Fetal compromise, therefore, cannot be detected by determining $\alpha_{1}$-AT levels. These levels, however, may be a guide to the onset of maternal complications during pregnancy. $\alpha_{1}-\mathrm{AT}$ is a fibrinolysis inhibitor and may be a cause of the thrombogenic tendency in pregnancy. ${ }^{75}$

In 1961, Alvarez and coworkers ${ }^{5}$ demonstrated the presence of a new $\alpha_{2}$ globulin in the blood of pregnant women. It was most prevalent during the third trimester and disappeared within eight weeks after delivery ${ }^{3.4}$ Although this protein has a number of different names, the designation pregnancy-zone protein (PZP) will be used throughout this discussion. PZP is absent from the cord blood and, therefore, is nonfetal in origin. The pregnancy zone does not correspond to any known protein. PZP has been shown not to be pregnancy-specific cystine aminopeptidase, human chorionic gonadotropin, pregnancy-specific alkaline phosphatase, ${ }^{65}$ human placental lactogen, ${ }^{26}$ or the four pregnancyassociated plasma proteins (PAPP's) discussed later in this paper. ${ }^{40} \mathrm{PZP}$ is identical immunologically to pregnancy-specific $\alpha_{2}$-macroglobulin, $\alpha_{2}$-pregnoglobulin, pregnancy-associated $\alpha_{2}$-globulin ${ }^{40}$ and the pregnancy protein $\mathrm{SP}_{3}$ of Bohn. ${ }^{6}$

Besides being found in pregnant women, the pregnancy zone has been found in non-pregnant women receiving antiovulatory drugs, ${ }^{3,13,14}$ in women with 
trophoblastic disease, ${ }^{64}$ in men therapeutically treated with estrogens, in some malignancies and in some non-neoplastic diseases.

The increase of PZP which accompanies pregnancy would be expected to have a definite function. The placental content of pregnancy zone protein can be accounted for by the maternal plasma present in the intervillous spaces. ${ }^{42}$ PZP has been found by indirect immunofluorescence to be localized in blood vessel walls, parenchymal structures within the villous, as well as the trophoblast cytoplasm. ${ }^{41}$ Since PZP is found in the trophoblast cytoplasm, it may have a localized function. The pregnancy zone protein could be involved in protecting the fetus from rejection by the mother. The fetus has histocompatibility antigens from the father, and the mother has the potential to mount a cell-mediated immune response against the fetus. PZP, then, could block the recognition or effector stages of the immune response. ${ }^{74}$ This hypothesis is supported by the lower levels of PZP encountered in prolonged pregnancy and in cases of abortion associated with placental destruction. In 31 cases of prolonged pregnancy, PZP was significantly lower than in normal pregnancy. ${ }^{79}$

\section{Etiology of Variations}

Numerous changes in protein concentrations during pregnancy have been documented with various opinions ventured to explain the reasons for these changes. One factor thought to be involved is the increase in plasma volume which occurs during pregnancy. ${ }^{50}$ The average total plasma volume increases from $2600 \mathrm{ml}$ in non-pregnant women to 3640 $\mathrm{ml}$ close to term. ${ }^{34}$ This would be expected to lower the concentrations of proteins, such as albumin. Increased albumin synthesis, to counteract this hemodilution, is thought to be inhibited by estrogen or progesterone. ${ }^{75}$ The effect of hormones, such as estrogen, upon pregnant women is another factor involved in the adjustment of protein concentrations since estrogen is known to increase as much as 10,000 times in pregnancy. ${ }^{58}$ Steroids are thought to influence protein synthesis on the nucleic acid level, thus causing a change in either the synthesis or the degradation of a protein.

A decrease in albumin, total protein and haptoglobin has been seen with administration of estrogen and estrogenprogesterone combinations. There is an elevation in ceruloplasmin, transcortin and thyroxine binding globulin, and no change in transferrin. Patients treated with estrogen plus progesterone show an increase in the pregnancy zone protein while no increase is seen with estrogen alone. ${ }^{65}$ Another study has shown highly significant increases in $\alpha_{2}$-macroglobulin, lipoprotein, plasminogen and $\alpha_{1}$-antitrypsin. $^{36}$ There was also a significant rise in transferrin and a fall in orosomucoid. The fall in orosomucoid and haptoglobin is greater than in pregnancy, while the elevation in $\alpha_{1}$-antitrypsin, $\alpha_{2}$ macroglobulin, lipoprotein and transferrin are less than those found during pregnancy. These results are shown in figure 1. This study implies that the metabolic effects of estrogen are only in partial agreement with the alterations occurring in normal pregnancy.

The influences on the steady state level of various proteins in pregnancy are impossible to predict, since catabolic pathways of many proteins are unexplored. It is reasonable that proteolytic enzymes are involved, and concentrations of these enzymes plus their inhibitors would also be affected by hormones. It is also possible that the concentrations of some proteins rise as a result of demand for increased functional capacities. ${ }^{51,58}$ Obviously, many factors are involved in establishing the concentration of proteins during normal pregnancy. 
PROTEIN CHANGES - CONTRACEPTIVE STEROIDS vs. PREGNANCY

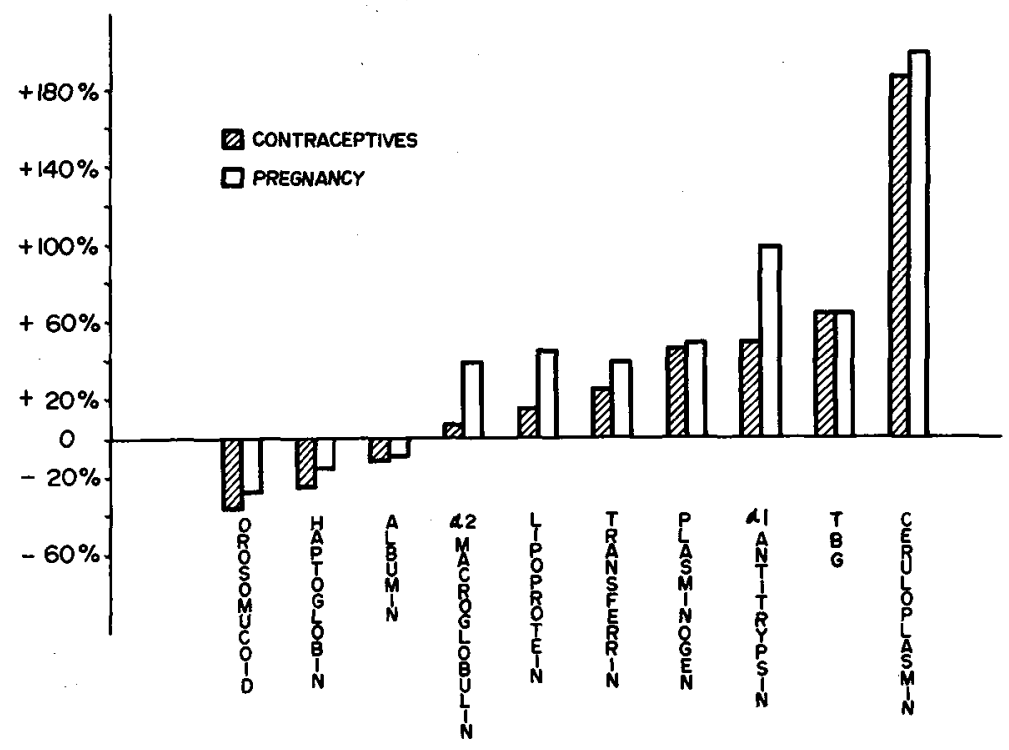

Figure 1. A comparison of the percent change from normal values of proteins after administration of anti-ovulatory drugs to non-pregnant women and during pregnancy.

\section{Pregnancy-Specific Proteins}

In contrast to the previously described proteins, which are present in all serum and merely change in concentration during pregnancy, there exists a group of proteins which appear only in the serum of pregnant women. In general, they are placental in origin and cannot be induced by estrogen therapy, nor are they usually present in any of the various carcinomas.

The serum of pregnant women contains a unique enzyme which is capable of inactivating oxytocin by cleavage of cystine. This enzyme has become known therefore as cystine aminopeptidase. ${ }^{80}$ The level of oxytocinase does not go down before or during labor. Onset of labor, therefore, is probably not the result of a loss of ability of plasma to inactivate oxytocin.

There are actually two cystine aminopeptidases (oxytocinases) with different electrophoretic mobility. $\mathrm{CAP}_{1}$ appears during the fourth month of gestation, while $\mathrm{CAP}_{2}$ is not evident until the third trimester. Since neither could be found in fetal blood, the placenta is assumed to be the source of the enzyme..$^{59,64}$

In 1972, Gall and Halbert ${ }^{19}$ reported the presence of up to four antigenic components in the serum of pregnant women. These proteins, which could be detected by the third trimester, were only present in pregnant females. The proteins will heretofore be referred to as pregnancyassociated plasma proteins (PAPP's), although various systems of nomenclature exist. Initial attempts to identify the PAPP's by immunodiffusion with the following polypeptide hormones showed no immunologic relationship: human chorionic gonadotropin (HCG), bovine prolactin and synthetic oxytocin. A similar test with C-reactive protein was also negative. None of the PAPP's had any acid or alkaline phosphatase, oxytocinase (cystine aminopeptidase), catalase, glucosamidase, estrase, glucuronidase or arylsulfatase activity. ${ }^{19,44}$

None of the proteins are apparently derived from the fetus because none of the four could be detected in cord blood or in amniotic fluid. The PAPP's are uniformly 
distributed throughout the cytoplasm of the villous trophoblast cells of the placenta, so all trophoblasts are apparently active simultaneously in the synthesis of the PAPP's. ${ }^{41,77}$

The PAPP's have been identified by their electrophoretic mobility. ${ }^{44}$ PAPP-B and PAPP-C migrate as $\beta$-globulins while PAPP-A and PAPP-D migrate as $\alpha_{2}$ globulins. PAPP-C consists of two immunoelectrophoretic fractions. ${ }^{43,44}$ One fraction (-C) migrates as $\beta$-globulin, while the other $\left(-C^{\prime}\right)$ does not migrate. On DEAE cellulose, PAPP-C is split into two overlapping fractions. ${ }^{44}$ When subjected to isoelectric focusing, the major fraction shows two bands, one with $\mathrm{pI}=3.8$ and the other with $\mathrm{pI}=6.0$. PAPP-C may be involved in iron transport. ${ }^{44}$

PAPP-D is identical immunologically to human placental lactogen (HPL), and PAPP-C is identical to the pregnancyspecific glycoprotein of Bohn.?

Lin and coworkers ${ }^{47}$ have determined the maternal levels of PAPP-A, PAPP-C and PAPP-D throughout pregnancy and after parturition. PAPP-A concentration reaches a maximum at term and has almost disappeared by the 16th day postpartum. The concentration of PAPP-C rises until the 35th week of gestation, after which time it remains essentially unchanged until term. After delivery, the level of PAPP-C decreases rapidly and disappears by approximately the 12th day postpartum. PAPP-D levels reach a maximum during the 33rd week and fall rapidly thereafter. By the first day postpartum, PAPP-D is undetectable in maternal plasma. Because of a lack of monospecific antiserum, PAPP-B could not be readily quantitated until recently.22 It reaches a maximum during the eighth month of gestation and is undetectable after about three days postpartum.

Levels of PAPP-A and PAPP-C during the last month of gestation are significantly higher in pregnancies involving male fetuses than in those involving female ${ }^{45}$ No male-female difference could be encountered in PAPP-D. A direct correleation between fetal size and PAPP-C has also been found. None of the PAPP's shows any statistically significant relationship with maternal age or race. PAPP-A and PAPP-D tend to be low during the last month of gestation in women who have had three or more previous full term or premature pregnancies. PAPP-A, PAPP-C and PAPP-D are all elevated in twin pregnancies. ${ }^{46,78}$

Tatra and coworkers ${ }^{78}$ have studied levels of PAPP-C $\left(\mathrm{SP}_{1}\right)$ in normal and abnormal pregnancies. No correlation could be found between PAPP-C levels and pregnancies involving diabetes or $\mathrm{Rh}$ incompatibility. In hypertensive disorders of pregnancy with a favorable prognosis, PAPP-C levels were within normal limits but tended to fall below the mean, whereas in cases with fetal or placental impairment, the levels were markedly reduced.

An unusual alkaline phosphatase is found in the serum of pregnant women. It appears between the 15th and 26th week of gestation and disappears by the sixth week postpartum. ${ }^{62,65}$ The same enzyme has been extracted from placental tissue, thus establishing the placenta as its source. ${ }^{65}$

Alkaline phosphatase of placental origin is a glycoprotein of known amino acid composition and is produced by the placental trophoblast. ${ }^{66}$ It differs from other alkaline phosphatases in its substrate specificity, heat stability, inhibition by amino acids and electrophoretic mobility. Since this isoenzyme has not been found in fetal serum, fetal bone, cord blood nor in serum of non-pregnant women, ${ }^{18}$ villous capillaries must present a barrier.

Human chorionic gonadotropin is secreted throughout normal pregnancy. It has been detected as early as six days after presumed conception with a radioimmunoassay method specific for $\beta$-HCG. Peak levels are found between 56 to 68 
days after conception. After 18 weeks, the levels of HCG are relatively low throughout pregnancy. ${ }^{9}$

There is an abnormality in the immunoelectrophoretic patterns of $\alpha_{1}$ lipoprotein in the serum of pregnant women. ${ }^{63}$ It consists of a prolongation of the precipitin line corresponding to $\alpha_{1}$ lipoprotein and appears after the 20th week of gestation. The abnormality may be related to the inhibition of fetal growth. Serum from pregnant women in the seventh to 13th week of gestation stimulates growth of HeLa cells in vitro, while serum from women beyond the 20th week of gestation inhibits growth of the cells. This inhibition seems to be associated with the appearance of the atypical $\alpha_{1}$ lipoprotein. It is unclear whether the protein is the cause of the inhibitory activity or merely associated with it.

\section{Placental Function Tests}

The serum level of alkaline phosphatase activity increases exponentially as a function of gestation time. ${ }^{18,66}$ The placental isoenzyme which can be measured indirectly by heat fractionation, has been utilized as an indicator of placental function. ${ }^{66}$ It is thought to play an important role in the feto-maternal immunologic relationship ${ }^{18}$ and may also be associated with placental maturity.

In the case of placental infarction, the placental isoenzyme would be released from the microvilli into the maternal circulation. This could be the explanation for the increase in concentration of this isoenzyme in patients with toxemia of pregnancy, since placental infarcts are often associated with toxemia. ${ }^{6}$

PAPP-C levels correlate well with placental weight and tend to fall outside the normal range in abnormal pregnancies. An interesting point is that PAPP-A is above normal in the majority of twin pregnancies. ${ }^{46}$

There is a correlation between PAPP-D (HPL) concentration and placental weight in normal pregnancy. ${ }^{81}$ Abnormally low PAPP-D concentrations after the 30th week of gestation are associated with fetal death. If the $L / S$ ratio is indicative of fetal maturity but the PAPP-D level is low, Spellacy ${ }^{71,72}$ has indicated that induced delivery might increase perinatal salvage.

\section{Hypertensive Disorders of Pregnancy}

In hypertensive disorders of pregnancy, concentrations of total protein and albumin continue to fall in the last three months of gestation, whereas normally the values are stable. ${ }^{49}$ Albumin, transferrin and hemopexin decrease in concentration, while $\alpha_{1}$-glycoprotein, $\alpha_{2}$-macroglobulin and $\beta$-lipoprotein increase. PAPP-A levels are elevated, while PAPP-C and PAPP-D as well as PZP, are unaltered in pre-eclampsia. ${ }^{76}$ There is an elevation of oxytocinase and a decrease in placental alkaline phosphatase. ${ }^{63}$ When patients with pre-eclampsia minus proteinuria and pre-eclampsia plus proteinuria were compared to normal pregnant women, the following results were observed ${ }^{28}$ In pre-eclampsia without proteinuria, albumin and transferrin levels were normal with decreases of 19 percent in $\alpha_{2}$-macroglobulin and 16 percent in IgG. When proteinuria accompanied pre-eclampsia, there was a marked fall of 21 percent in albumin and an increase of 55 percent in $\alpha_{2}$-macroglobulin.

Pregnancy-associated $\alpha_{2}$-macroglobulin (PAM) is thought to have immunosuppressive properties. In certain pathological pregnancies including preeclampsia, low levels of PAM are found.$^{74}$ In normal pregnancies, the percentage of immunologically inactivated serum oxytocinase, a pregnancy-specific cystine aminopeptidase, is maximum at term. In patients with severe preeclampsia, however, the maximum inactivation occurs several weeks prior to delivery. ${ }^{83}$ In these patients, a percentage of maternal oxytocinase may possess molecular determinants which cross-react with placental anti-oxytocinase. 
The electrophoretic distribution of serum proteins in preeclampsia is similar to that occurring in nephrotic syndrome. ${ }^{5}$ In both situations, there is proteinuria, edema, a decrease in albumin and an increase in $\alpha_{2}$-macroglobulin. ${ }^{28}$ In nephrotic syndrome, the elevation of $\beta$-lipoprotein and $\alpha_{2}$-macroglobulin is the result of nonspecific synthesis of proteins after a loss of protein in the urine. There is a loss of proteins of intermediate molecular weight, such as albumin (MW 69,000), hemopexin (MW 80,000) and transferrin (MW 90,000), and a retention of large proteins such as $\alpha_{2}$-macroglobulin (MW 820,000 ) and $\beta$-lipoproteins (MW $\left.3.2 \times 10^{6}\right)$ which are too large to pass the defective glomerular basement membrane. ${ }^{76}$ This may also be the case in preeclampsia.

Other theories have been proposed to explain the changes observed in hypertensive disorders of pregnancy. It is possible that some morphological changes in the liver may be associated with the depression of the synthesis of certain proteins. ${ }^{76}$ It is also possible that the changes in protein concentration could be dependent upon hormone changes. There is some indication of decreased production of estrogens in pre-eclampsia. ${ }^{32}$ The similarity to the nephrotic syndrome appears to be the most widely held theory at this time.

\section{References}

1. Aboul-Khair, S. A., Crooks, J., Turnball, A. C., and HYLTEN, F. E.: The physiological changes in thyroid function during pregnancy. Clin. Sci. 27:195-207, 1964.

2. Afonso, J. F. and DE Alvarez, R. R.: Further starch gel fractionation of new protein zones in pregnancy. Amer. J. Obstet. Gynec. 86:815$819,1963$.

3. Afonso, J. F. and DE Alvarez, R. R.: New electrophoretic zone in pregnancy. Amer. J. Obstet. Gyne. 89:204-214, 1964.

4. AFonso, J. F. and Farnham, N. G.: Studies of a new electrophoretic zone in labor and the puerperium and in newborn infants. Amer. $J$. Obstet. Gynec. 84:199-205, 1962.

5. DE Alvarez, R. R., Alfonso, J. F., and SherRARD, D. J.: Serum protein fractionation in normal pregnancy. Amer. J. Obstet. Gynec. $82: 1096-1111,1961$.
6. BOHN, H.: Immunochemical determination of human pregnancy proteins. Arch. Gynäk. 217:219-231, 1974.

7. BoHN, H.: Nachweis und Charakterisierung von Schwanger-schafts-protein in der Menschlichen Placenta sowie ihre Quantitative Immunologische Bestimmung im serum Schwangerer Frauen. Arch. Gynäk. 210:440 457, 1971.

8. Braunstein, G. D. and Hershman, J. M.: Comparison of serum pituitary thyrotropin and chorionic gonadotropin concentrations throughout pregnancy. J. Clin. Endocrinol. Metab. 42:1123-1126, 1976.

9. Braunstein, G. D., Rasor, J., Adler, D., DANZER, II., and WADE, M. E.: Serum human chorionic gonadotropin levels throughout pregnancy. Amer. J. Obstet. Gynec. 126:678$681,1976$.

10. Clarke, H. G. M., Freeman, T., and PrysePhILlips, W.: Serum proteins in normal pregnancy and mild pre-eclampsia. J. Obstet. Gynaec. Brit. Comm. 78:105-109, 1971.

11. Cohen, H., Graham, H., and LaU, H. L.: Alpha-l fetoprotein in pregnancy. Amer. J. Obstet. Gynec. 115:881-883, 1973.

12. Coryell, M. N., Beach, E. F., Robinson, A. R., MACY, I. G., and MACK, H. C.: Metabolism of women during the reproductive cycle. XVII. Changes in electrophoretic patterns of plasma proteins throughout the cycle and following delivery. J. Clin. Invest. 29:1559-1567, 1950.

13. Damber, M. G., Schoultz, B. V., Stigbrand, T., and CarLström, K.: Serum levels of pregnancy zone proteins during the normal menstrual cycle. Acta Obstet. Gynec. Scand. $55: 467-468,1976$.

14. Damber, M. G., Schoultz, B.V., Stigbrand, T., and CARLSTRÖM, K.: Induction of a pregnancy zone protein by conjugated estrogens. Acta Obstet. Gynec. Scand. 55:321-323, 1976.

15. DoE, R. P., Dickinson, P., Zinneman, H. H. and SEAL, U. S.: Elevated non-protein-bound cortisol (NPC) in pregnancy, during estrogen administration and in carcinoma of the prostate. J. Clin Endocrinol. Metab. 29:757-766, 1969.

16. Dowling, J. T., Freinkel, N., and IngBar, $\mathbf{S}$. $H .:$ Thyroxine-binding by sera of pregnant women. J. Clin Endocrinol. Metab. 16:280-282, 1956.

17. Fedete, K.: Beiträge zur Physiologie der Gravidität. Endokrinology 7:364-369, 1930.

18. Fishman, W. H., BardaWHIL, W. A., HaBIB, H. G., ANstiss, C. L., and GREEN, S: The placental isoenzyme of alkaline phosphatase in sera of normal pregnancy. Amer. J. Clin. Path. 57:6574, 1972.

19. Gall, S. A. and Halbert, S. P.: Antigenic constituents in pregnancy plasma which are undetectable in normal non-pregnant female or male plasma. Int. Arch. Allerg. 42:503-515, 1972.

20. Gankot, P. O. and BjerRe, B.: $\alpha_{1}$-Antitrypsin and $\alpha_{2}$-macroglobulin concentration in serum during pregnancy. Acta Obstet. Gynec. Scand. 46:126-137, 1967.

21. Genazzani, A. R., Fionetti, P., and LEMARCHAND-BERAND, Th.: Plasma thyrotro- 
pin levels during pregnancy. J. Obstet. Gynaec. Brit. Comm. 78:117-122, 1971.

22. Halbert, S. P.: Private communication, 1977.

23. HANKIEWICZ, V. J. and SEVECEK, E.: Untersuchungen über den Kupfer und Zeruloplasmingehalt bei Frauen währendder Schwangerschaft und bei solchen mit gewissen gynäkologischen Krankheeten. Zbl. Gynäk. 96:905-909, 1974.

24. Hay, D. M., Forrester, P. I., HaNcock, R. L., and LORSCHNEIDER, F. L.: Maternal serum alpha-fetoprotein in normal pregnancy. Brit. J. Obstet. Gynaec. 83:534-538, 1976.

25. HILlMAN, L., SCHONFELd, G., MILLER, J. P., and WULFF, G.: Apolipoproteins in human pregnancy. Metabolism 24:943-952, 1975.

26. Hofmann, R., Straube, W., Klausch, B., Friemel, H., and Gunther, J.: Immunchemische Untersuchungen zum Problem dur "Pregnancy Zone." VI. Vorkommen, Identifizierung und Nachweis des schwangerschaftstrypischen Proteins der Schwangerschaftszone. Arch. Gynäk. $212: 246-257,1972$.

27. HöNGER, P. W.: Albumin metabolism in normal pregnancy. Scand. J. Clin. Lab. Invest. $21: 3-9$, 1968.

28. Horne, C. H. W., Howte, P. W., and Goudie, R. B.: Serum alpha - $_{2}$ acroglobulin, transferrin, albumin and IgG levels in preeclampsia. J. Clin. Path. 23:514-516, 1970 .

29. KaISER, R., Berk, J. E., and Frudhandler, L.: Serum amylase changes during pregnancy. Amer. J. Obstet. Gynec. 122:283-286, 1975.

30. Kannan, V., Sinka, M. K., DEVI, P. K., and RasTOGI, G. K.: Plasma thyrotropin and its response to thyrotropin releasing hormone in normal pregnancy. Obstet. Gynec. 42:547-549, 1973.

31. KenNAN, A. L. and BELL, W. N.: Blood coagulation during normal pregnancy, labor, and the puerperium. Amer. J. Obstet. Gynec. 73:57-64, 1957.

32. KLOPPER, A.: The assessment of feto-placental function by estriol assay. Obstet. Gynec. Survey 23:813-838, 1968.

33. KULIC-JAPUNDUK, I.: Lipids of the serum in normal pregnancy. III. Non-esterified fatty acids in the serum of pregnant women and their relation to lipoproteins of the serum. Ann. Biol. Chim. 19:143-147, 1961.

34. LANGE, R. D. and DyNEsIUS, R.: Blood volume changes during normal pregnancy. Clinics in Haematol. 2:433-451, 1973.

35. LAU, H. L. and Linkins, S. E.: Alphafetoprotein. Amer. J. Obstet. Gynec. 124:533$554,1976$.

36. LAURELl, C. B., Kullander, S., and Thorell, J.: Effect of administration of a combined estrogen-progestin contraceptive on the level of individual plasma proteins. Scand. J. Clin. Lab. Invest. $21: 337-343,1968$

37. LeEK, A. E., Ruoss, C. F., Krtau, M. J., and CHARD, T.: Maternal plasma alphafetoprotein levels in the second half of normal pregnancy: relationship of fetal weight, maternal age and parity. Brit. J. Obstet. Gynaec. 82:669-673, 1975.
38. LEMARCHAND-BÉRAUD, Th. and MEÁ́, P.: Pituitary regulation of thyroid in pregnancy. Horm. Metab. Res. 2:338-343, 1970.

39. LIDDELow, B: Levels in normal non-pregnant and pre gnant women. Med. J. Aust. 2:332-334, 1953.

40. LIN, T. M. and Halbert, S. P.: Immunological comparison of various human pregnancyassociated plasma proteins. Inter. Archs. Allergy Appl. Immun. 48:101-115, 1975.

41. LiN, T. M. and Halbert, S. P.: Placental localization of human pregnancy-associated plasma proteins. Science 193:1249-1252, 1976.

42. LIN, T. M., Halbert, S. P., and KIEFER, D.: Quantitative analysis of pregnancy-associated plasma proteins in human placenta. J. Clin. Invest. $57: 466-472,1976$.

43. LiN, T. M., Halbert, S. P., Kiefer, D., and SPELLACY, W. N.: Three pregnancy-associated human plasma proteins: purification monospecific antisera and immunological identification. Int. Arch. Allerg. 47:35-53, 1974.

44. LiN, T. M., HalberT, S. P., Kiefer, D., SPelLACY, W. N., and GAL, S.: Characterization of four human pregnancy-associated plasma proteins. Amer. J. Obstet. Gynecol. I18:223-236, 1974.

45. LIN, T. M. Halbert, S. P., and SPellacy, W. N.: Measurement of pregnancy-associated plasma proteins during human gestation. J. Clin. Invest. 54:576-582, 1974.

46. LiN, T. M. Halbert, S. P., Spellacy, W. N., and BERNE, B. H.: Plasma concentrations of four pregnancy proteins in complications of pregnancy. Amer. J. Obstet. Gynec. 128:808810,1977

47. LiN, T. M., Halbert, S. P., Spellacy, W. N., and GALL, S.: Human pregnancy-associated plasma proteins during the postpartum period. Amer. J. Obstet. Gynec. 124:382-387, 1976.

48. LiU, D. T. Y. and GRUNDY, E. N.: An evaluation of alpha $a_{1}$ antitrypsin in the antenatal period. Brit. J. Clin. Pract. 30:168-170, 1976.

49. MacGillivray, I. and TOVEY, J. E.: A study of the serum protein changes in pregnancy and toxaemia, using paper strip electrophoresis. J. Obstet. Gynac. Brit. Emp. 64:361-364, 1957.

50. Malkasian, G. D. and MayberRy, W. E.: Serum total and free thyroxin and thyrotropin in normal and pregnant women, neonates, and women receiving progestogens. Amer. I. Obstet. Gynec. 108:1234-1238, 1970.

51. MendenhalL, H. W.: Serum protein concentrations in pregnancy. 1. Concentrations in maternal serum. Amer. J. Obstet. Gynec. 106:388-399, 1970 .

52. Mora, R., RebeyotTe, P., and Polonovski, J.: Influencedes substances tensio actives sur la mobilité electrophoretique des lipoproteides plasmatiques. J. Bull. Soc, Chem. Biol. 37:957-968, 1955.

53. Mulaisho, C. and Utiger, R. D.: Serum thyroxine binding globulin: determination by competitive ligand binding assay in thyroid disease and pregnancy. Acta Endocrinol. 85:314-324, 1977. 
54. MusA, B. U,, DoE, R. P., and SEAL, U. S.: Elevation of certain plasma proteins in man following estrogen administration: A dose-response relationship. J. Clin. Endocrinol. Metab. 25:1163$1166,1965$.

55. MUSA, B. U., DOE, R. P., and SEAL, U. S.: Serum protein alterations produced in women by synthetic estrogens. J. Clin. Endocrinol. Metab. 27:1463-1469, 1967.

56. Nyman, M. : Serum haptoglobin. Scand. J. Clin. Lab. Invest. 11 (Suppl. 39), 1959.

57. Ondley, J. L., GuRd, F. R. N., and MELiN, M.: Preparation and properties of serum and plasma proteins. XXV. Composition and properties of human serum $\beta$-lipoprotein. J. Amer. Chem. Soc. 72:458-464, 1950.

58. PaABY, P.: Changes in serum proteins during pregnancy. J. Obstet. Gynaec. Brit. Comm. $67: 43-55,1960$.

59. Page, E. W., Trtus, M. A., Mohun, G., and Glendening, M. B.: The origin and distribution of oxytocinase. Amer. J. Obstet. Gynec. $82: 1090-1095,196:$.

60. PfaU, P.: Die Serumerhältnisse Währendder Normalen und Gestörten Schwangerschaft. Arch. Gynäk, 185:188-207, 1954.

61. Rastogi, G. K., Sawbrey, R. C., Sinha, M. K., Thomas, Z., and DEVI, P. K.: Serum and urinary levels of thyroid hormones during normal pregnancy. Obstet. Gynec. 44:176-180, 1974.

62. Reboud, P., Groulade, J., Groslambert, P., and Colomb, M.: The influence of normal pregnancy and the postpartum state on plasma proteins and lipids. Amer. J. Obstet. Gynec. $86: 820-828,1963$.

63. Rejnek, J,, Bednarik, T., Rerabkova, E., and DOLEZAL, A.: Investigations of the influence of sera from pregnant women on the growth of cell cultures in conjunction with occurrence of abnormal $\alpha_{1}$-lipoprote in. Clin. Chim. Acta 8:108 115, 1963.

64. Robinson, J. C., London, W. T., and Pierce, J. E.: Observations on the origin of pregnancyassociated plasma proteins. Amer. J. Obstet. Gynec. 96:226-230, 1966.

65. Robinson, J. C., Pierce, J. E., and Blumberg, B. S.: The serum alkaline phosphatase of pregnancy. Amer. J. Obstet. Gynec. 94:559-565, 1966.

66. Romslo, I., Sagen, N., and Haram, K.: Serum alkaline phosphatase in pregnancy. Acta Obstet. Gynec. Scand. 54:437-442, 1975.

67. Rosenthal, H. E., Slaunwhite, W. R., and SANDBERG, A. A.: Transcortin: A corticosteroid-binding protein of plasma. X. Cortisol and progesterone interplay and unbound levels of these steroids in pregnancy. J. Clin. Endocrinol. Metab. 29:352-367, 1969.

6̄. SChenker, J. G., Ben-David, M., and PoHSHEIT, W. Z.: Prolactin in normal pregnancy: Relationship of maternal, fetal, and amniotic fluid levels. Amer. J. Obstet. Gynec. 123:834$838,1975$.

69. Seppala, M. and Ruoslahti, E.: Alpha fetoprotein in maternal serum: a new marker for de- tection of fetal distress and intrauterine death. Amer. J. Obstet. Gynec. 115:48-52, 1973.

70. Song, C. S., Merkatz, I. R., Rifkind, A. B., Gillette, P. N., and Kappas, A.: The influence of pregnancy and oral contraceptive steroids on the concentration of plasma proteins. Amer. J. Obstet. Gynec. 108:227-231, 1970.

71. Spellacy, W. N., Bufi, W. C., and Birk, S. A.: The effectiveness of human placental lactogen measurements as an adjunct in decreasing perinatal deaths. Amer. J. Obstet. Gynec. 121:835-844, 1975 .

72. Spellacy, W. N., Usategui-Gomez, M., and Fernandez-de Castro, A.: Plasma human placental lactogen, oxtyocinase and placental phosphatase in normal and toxemic pregnancies. Amer. J. Obstet. Gynec. 127:10-16, 1977.

73. STandeven, R. M.: Thyroid function tests during pregnancy, the normal menstrual cycle and in women using oral contraceptives. J. Endocrinol. 43:217-224, 1969.

74. Stimson, W. H.: Studies on the immunosuppresive properties of a pregnancyassociated $\alpha$ macroglobulin. Clin. Exp. Immunol. 25:199-206, 1976.

75. Studd, J. W. W., Blainey, J. D., and Bailey, D. E.: A study of serum protein changes in late pregnancy and identification of the pregnancy zone protein using antigen-antibody crossed immunoelectrophoresis. J. Obstet. Gynaec. Brit. Comm. 77:42-51, 1970.

76. Studd, J. W. W., BAlinEY, J. D., and Balley, D. E.: Serum protein changes in the preeclampsia-eclampsia syndrome. J. Obstet. Gynaec. Brit. Comm. 77:796-801, 1970.

77. Tatarinov, Y. S. FalaleEva, D. M., Kalashnikov, U. U., and TOLknOV, B. O.: Immunofluorescent localisation of human pregnancy-specific $\beta$-globulin in placenta and chorioepithelioma. Nature 260:263, 1976.

78. Tatra, G., Breitenecker, G., and Gruber, W.: Serum concentration of pregnancyspecific $\beta$-l-glycoprotein (SP-1) in normal and pathologic pregnancies. Arch. Gynäk. 217:383-390, 1974.

79. Than, G. N., Csaba, D. G., KarG, N. J., and NorAK, P. F.: Quantitative immunological study of pregnancy-associated $\alpha_{2}$-globulin antigen. Vox Sang. 30:134-138, 1976.

80. Titus, M. A., Reynolds, D. R., Glendening, M. B., and PAGE, E. W.: Plasma aminopeptidase activity (oxytocinase) in pregnancy and labor. Amer. J. Obstet. Gynec. 80:1124-1128, 1960.

81. Towler, C. M., Horne, C. H. W., Jandial, V., Camperll, D. M., and MacGillivray, I.: Plasma levels of pregnancy-specific $\beta_{1^{-}}$ glycoprotein in normal pregnancy. Brit. J. Obstet. Gynaec. 83:775-779, 1976.

82. TySON, J. E., HWANG, P., GuYdA, H., and FRIESEN, H. G.: Studies of prolactin secretion in human pregnancy. Amer. J. Obstet. Gynec. 113:14-20, 1972.

83. Watkins, W. B. and SmalL, C. W.: Immunologic inactivation of human pregnancy serum oxytocinase activity. Amer. J. Obstet. Gynec. 113:973-978, 1972. 